\title{
The Olive Growing Agri-Industrial District of Jaén and the International Olive Oils Cluster
}

\author{
Juan Carlos Rodríguez-Cohard* and Manuel Parras
}

Department of Economics, University of Jaén, Spain

\begin{abstract}
This article presents olive oil production from both the cluster and the industrial perspective. We distinguish both concepts to interpret the current reality from a territorial point of view. In this sense, we use the notion of the agriindustrial district to explore olive growing activity in the province of Jaén, due to the special social and historic relations that are involved in the organisation of production. On the other hand, we use the cluster concept to characterise organisational proximity linked to different companies which form the international olive oil value chain.

The agri-industrial district has focused its attention on the production of oil to be sold in the intra-industrial bulk unbottled oils market. But new challenges are taking place upstream in the cluster, with new players emerging, especially in the distribution channels. In addition, downstream, we are observing the emergence of new industrial and service activities that could pave the way for the next structural changes in the rural development process in Europe.
\end{abstract}

Keywords: Olive growing, agri-industrial district, olive oils cluster.

\section{INTRODUCTION}

The last 25 years have witnessed increasing recognition of the importance of a number of key factors that interact to foster economic development -namely business activity, society, public and private-sector organisations, culture and physical resources. Analysis at 'grass roots' level provides the most accurate and realistic insights into production activity and how process improvements can be made, with a view to achieving greater production quotas, employment, and ultimately wealth for the population at large.

For businesses to achieve lasting competitive advantage, they therefore require an analysis of those factors that contribute to growing yields in their given territory, drawing on external economies provided by the local operating and institutional environment. In this sphere of research it is widely recognised that businesses do not compete in isolation, but rather within, and together with, the operating environment in which they develop. It is for this reason that identifying clusters and territorial production environments is of vital importance when seeking to understand the competitive characteristics of any region, in light of the current globalisation process.

Since Porter's [1] studies on competitive advantage in specific territory-based clusters were first applied, numerous other studies have emerged on the subject of territorial industrial agglomerations. Both this concept and other conceptual models such as the industrial district [2] or the milieu innovateur [3] ${ }^{1}$ have been used as a framework of

*Address correspondence to this author at the Department of Economics, University of Jaén, Spain; Tel: 0034-953212069; Fax: 0034-953212077;

E-mail: jccohard@ujaen.es

${ }^{1}$ We will look more closely at these concepts and their meanings later in this article. reference. That said, these particular perspectives have not been extensively applied to the agri-food sectors, although there are a few recent works. In the case of Spain, these include, amongst others: a study of the Almeria agri-food complex [4, 5] an identification analysis within the Jaén olive oils sector [6, 7]; a study of local agri-food production systems in Castilla y León [8]; and work on wine production in La Rioja [9].

In the rest of Europe, outstanding amongst recent works are: the analysis of Holland's horticulture [10]; the analysis of the French wine-growing cluster [11]; several Italian studies, such as the work on Piceno as a diverse agri-industry [12]; or works related to the concept of localised agri-food systems [13-17].

World-wide, works of note include those from a range of sectors in: Latin America [18, 19]; Chile [20]; Canada [21]; and the United States [22]. Also noteworthy is the work carried out under the auspices of the United Nations strategy for improving economic development and reducing poverty in developing countries [23].

The aim of the present article is to describe the structure of the olive growing agri-industrial district in Jaén province, and its relationships with the olive oils cluster in which it is a key player. This key role is thanks not only to being the supplier of the primary raw material, but also to its involvement in the olive oils market - primarily selling unbottled oils in bulk - with the cluster forming a powerful cooperative movement. Thus olive producers - the olive being the principal raw material in producing olive oils - are, when grouped together in cooperatives, one and the same as those who transform that raw material into the finished product and then commercialise it. It is this feature that distinguishes the Spanish case from that of Italy or Greece, for instance. In this context, the key contribution of the present work lies in its analysis of this activity from within the territorial paradigm of the district, transcending and 
embracing the sectorial perspective. This approach offers tremendous scope for future analyses in the realms of innovation process transfer and the identification of institutional barriers to developing and creating competitive advantage. It may also contribute to opening up new lines of territorial-based research amongst those research groups with a long-standing interest in the study of the olive growing sector and the olive oils market in Europe.

Against this backdrop, in the second section we present Jaén's olive grove production activity. As well as being closely linked to actually making the olive oil ${ }^{2}$, for centuries it has also been inseparable from the land and society of Jaén, and as such has shaped the local culture and economy. In section 3 we outline the concepts of industrial district and cluster as theoretical constructs with which to understand production activity in the territory, thus demonstrating their validity in different spheres of competition. The fourth section provides a description of the olive growing agriindustrial district in Jaén and its role in the olive oils cluster in a world-wide context. This shows the relationships between local players within the national and international olive oils cluster. In the fifth section the challenges facing the agri-district are outlined from a territorial perspective. Finally the article presents a series of conclusions and recommended actions.

\section{OLIVE GROWING AND JAÉN}

The province of Jaén is one of the eight provinces that make up the Autonomous Community of Andalucía (see Maps 1, 2), in Southern Spain. It covers $13,482 \mathrm{~km}^{2}$ and has a population of 667,502 - a density of 49 inhabitants per $\mathrm{km}^{2}$. The main urban areas are Jaén (116,557 inhabitants), Linares $(61,338$ inhabitants), Andujar $(39,111)$ and Ubeda $(35,649)$, which together constitute a network of almost 100 localities with significant links to olive growing [24].

The production structure of the province of Jaén is very much linked to agriculture and is centred mainly on olive groves, which account for $86 \%$ of farmed land [27]. Some $12.4 \%$ of the active population is devoted to agriculture, compared to $8.2 \%$ across Andalucía and $4.1 \%$ throughout Spain as a whole [28]. The gross value-added of Jaén's agriculture is $9.29 \%$ of the total, whilst in Andalucía it stands at $4.46 \%$, and in Spain, at just $2.73 \%$ [29]. Furthermore, according to the 1999 Agriculture Census, olive groves in Andalucía account for around $32 \%$ of the workforce throughout the entire agricultural and livestock sector. This is higher even than in sectors that have been particularly dynamic in recent years, such as horticulture and fruit and citrus production [30]. The Ministry for Agriculture and Fishing of the Junta de Andalucía estimated that, in the current season 2009-2010, in Jaén province olive harvesting would generate some 6,770,000 working days. If alongside this data we take into account the fact that olive groves

\footnotetext{
${ }^{2}$ Olive oils are classified according to quality, depending on physicalchemical parameters and organoleptic properties. Thus there are edible virgin olive oils (extra virgin and virgin), and those classified as not fit for consumption (lampante). The latter must undergo a refining process in order to obtain refined olive oils. Finally, there is 'olive oil' which is obtained by mixing edible virgin olive oils with refined olive oils. Out of all the olive oils mentioned here, only extra virgin olive oils, virgin olive oils and olive oils can be offered direct to the consumer. Furthermore, although not a type of olive oil, olive pomace oil is also available in the consumer market.
}

require industrial intervention in order to transform the olive into the finished product, it becomes clear just how important activities associated with the olive grove and olive oils are in this territory.

Olive growing is deeply rooted in the social and cultural fabric of Jaén, going back to at least the $2^{\text {nd }}$ Century. It was not until the $16^{\text {th }}$ Century, however, that the crop began to see wave after wave of sustained expansion, spreading out from the low-lands and gradually taking the place of other crops, principally cereals [31]. That said, it was only in the 20th Century that it assumed the prominence that it enjoys today. This was largely thanks both to the technical innovations that led to a higher quality product, and also to changes in the world oils market, which meant that the final product was no longer being used for industrial purposes such as fuel for lamps or in soap production - and instead became established as a foodstuff [32].

Thus, four stages can be defined in the development and consolidation of olive growing as the territory's primary activity:

1. The first third of the 20th Century: initial expansion. Characterised by an increase in harvesting and quality, thanks to the introduction of innovations to traditional production processes [33]. These developments lead Jaén province to become the number one producer world-wide. With this positive outlook, further development was possible and the extent of the crop was expanded, increasing both the number of almazaras ${ }^{3}$ and also of orujeras ${ }^{4}$. The first cooperative movements start to emerge [34].

2. 1936 (Spanish civil war) - 1958 (Spain's entry into international bodies): standstill.

3. 1959-1985: expansion in olive growing begins to pick up once more, with olive groves now covering even steeper, craggier terrain. Agricultural workers consolidate the cooperative movement in order to join forces in oil production, as a response to adverse conditions in the otherwise unprofitable local olive market. Retraining, to reflect mechanisation of the production process and agricultural tasks, at a time when the Spanish society and economy were undergoing a profound process of deagriculturalisation. Exploitation of the land grows significantly, with the introduction of irrigation using increasingly advanced techniques such as drip irrigation [35].

4. 1986-present day: entry into the European Union. This phase witnesses an increase in world-wide consumption of olive oils. This is due to the concept of olive oils as a healthy product, and to a noticeable increase in product quality, the latter thanks to mechanised harvesting and better use of technology in oil extraction. Growth in consumption, together with participation in the Common Agricultural Policy, helps increase profits for farmers which, in

\footnotetext{
${ }^{3}$ Mill where olives are ground down to produce edible and inedible virgin olive oils.

${ }^{4}$ Mill that uses pomace (orujo), a by-product of the oils, in order to make pomace oil, which is of inferior quality to olive oil.
} 


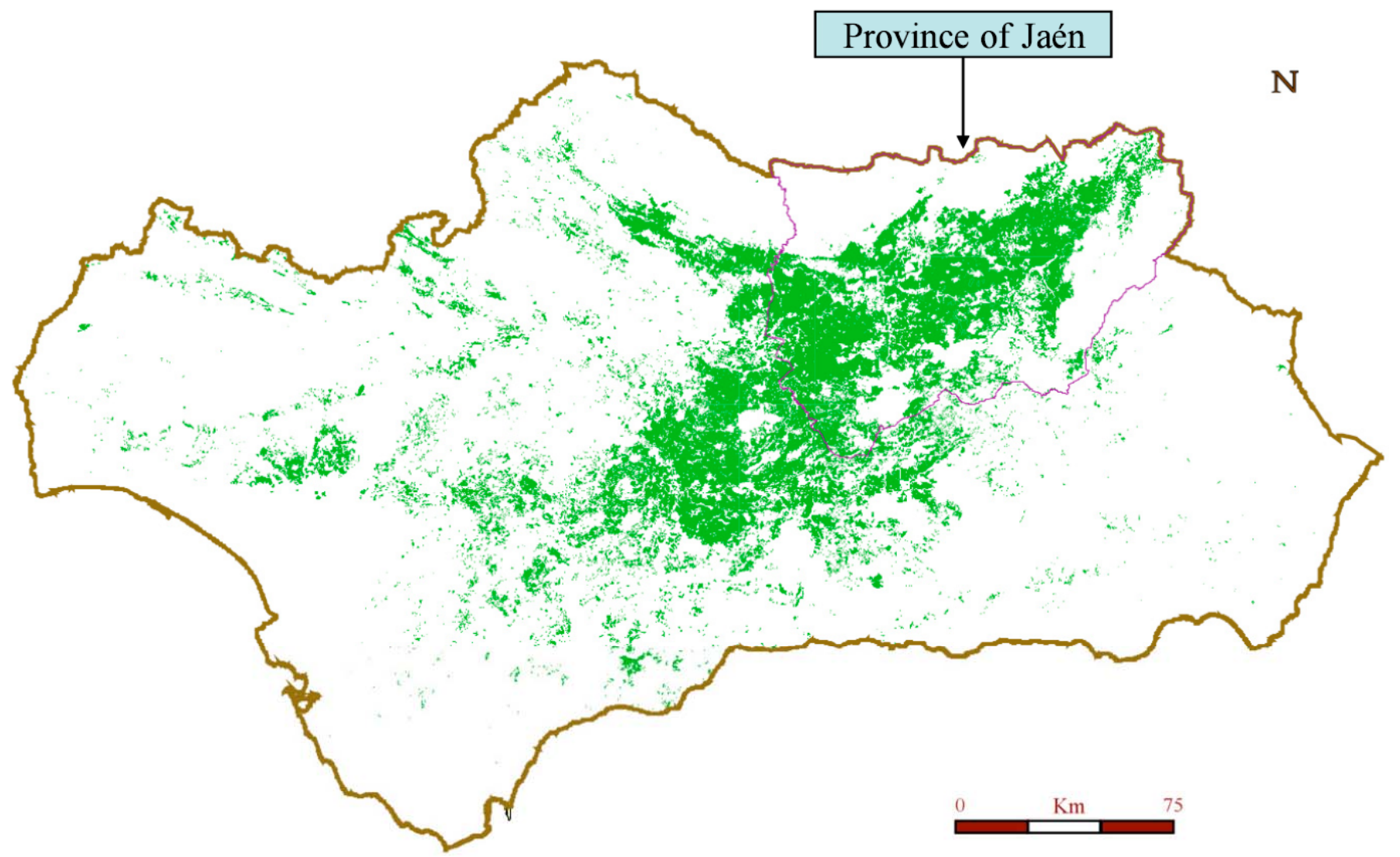

Map 1. Location of olive groves in Andalucía (see Map 2). Source: [25].

turn, further boost expansion in the crop, ups investment in cultivation and leads to more widespread irrigation. As a result, the olive growing sector becomes an investment target for other local production sectors - a safe haven for financial surpluses from other industries or services. The price of land goes up and there is continued expansion of the crop throughout uncultivated areas or where the land was traditionally used for other products. There is growing interest in trading directly with the endmarket, and some local brands enter the market with Denominaciones de Origen Protegidas (Protected Guarantee of Origin) status. The phenomenon of the part-time or weekend farmer ${ }^{5}$ becomes firmly established and the cooperative movement amongst farmers becomes a key plank in the future of olive growing not only in Jaén, but in the whole of Andalucía. The movement is even further stimulated by the creation of second and third-tier cooperatives ${ }^{6}$. Objectives include improving retail trade in local olive oils and strengthening competitive positioning relative to major industries and world-wide distributors.

\footnotetext{
${ }^{5}$ Farmer who is principally devoted to some other industrial activity or service and who keeps the olive grove mainly due to a family or cultural connection rather than as his main source of income.

${ }^{6}$ These are cooperatives made up not of individual farmers, but of cooperatives joining forces. Second-tier cooperatives are made up of a number of independent or first-tier cooperatives; and when second-tier cooperatives unite, this is known as a third-tier cooperative.
}

As can be discerned from this brief historical overview of olive growing in Jaén, there is a strong link between local society and economic activity associated with olive oils. Seen from this perspective, the agri-industry becomes the backbone of everyday life for this territory, overshadowing even the economic sphere and being all-pervasive in the cultural dynamic. It is these factors that lead us to put forward an analysis of this activity from within the theory of industrial districts [2]. We will use the concepts previously outlined, namely that of the cluster [1] and of the innovative milieu [3], as reference points in seeking to attain an integrated vision for olive growing and olive oils in Jaén.

\section{THE TERRITORIAL PERSPECTIVE ON OLIVE GROWING AND OLIVE OILS IN JAÉN: CLUSTER OR AGRI-INDUSTRIAL DISTRICT?}

The territorial perspective is that which takes a territory to be a complex network of physical, social, cultural and institutional resources that can be drawn-upon in order to generate wealth and employment. As such, the territory constitutes a strategic network that provides certain advantages that are not available in the market or within businesses.

These advantages come about by taking advantage of external economies - that is to say, economies external to each business but internal to the territory. This therefore turns into a system capable of facilitating each entity's everchanging 'fit' with the operating environment, by making it possible to avoid the law of diminishing returns coming into play. 


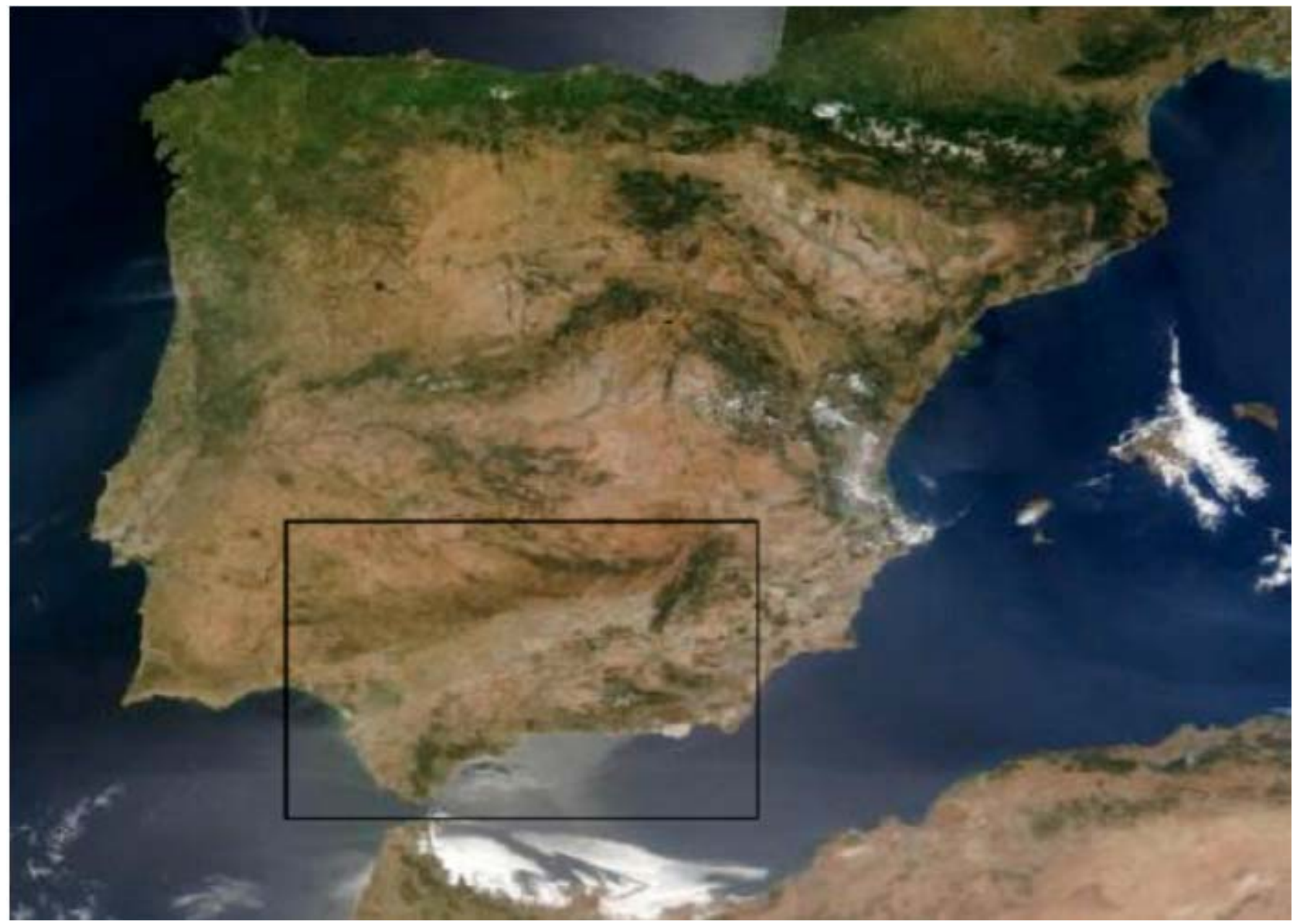

Map 2. Location of Andalucía in Spain. Source: [26]. Adapted in-house.

As stated earlier, this study of external economies that can be exploited from within the territory has mainly been conducted in light of two key concepts: the cluster - "a geographically proximate group of interconnected companies and associated institutions in a particular field, linked by commonalities and complementarities" [26, p.15]; and the industrial district - "a socioterritorial entity which is characterised by the active presence of both a community of people and a population of firms in one naturally and historically bounded area. In the district - unlike in other environments, such as the manufacturing town - the community and the firms tend, as it were, to merge" [36, p.9]. Both concepts came about in an attempt to understand the industrial reality that is found in specific locations. However they have also been applied in the agri-industrial field, as outlined at the beginning of this article, as they are used to analyse activity within a territory and can therefore go beyond the industrial realm, to include both services and agrarian activity.

Either way, studies that take these two perspectives as a reference point have one thing in common, namely that they combine a territorial approach, with a vertical take on the activity under study. That is to say, they follow the value chain or filiére analysis models that overcome horizontal sectorial distinctions and enable researchers to study 'real world' activities with greater accuracy. In the case of olive oil production, the value chain starts with supplies, with the inputs that farmers need: land, plants, fertilisers, machinery and so on. It continues with the extraction of the oil once the farmer's end-product has been ground, together with intermediary inputs, machinery, transport, administration and so forth. It ends with distribution of the oil and with the agents that take part in the process. In addition, as we will see in the next section, the activity is completed by a series of public and private agents that make up the various bodies and institutions that operate in the different phases of the business process, in line with specific functions that are shaped by the territorial and sectorial area in which they are carried out.

That said, there are clear differences between the concepts of cluster and district. Porter y Ketels [37] set out the key ones:

1. The industrial district refers to agglomerations of small industries in light industrial sectors, whereas a cluster does not distinguish between sizes and sectors. Hence for these authors, the district is a particular kind of cluster.

2. The district places greater emphasis on social and cultural conditions, which even extend to part-time work as an element of flexibility. 
3. The concept of the cluster comes from the academic realm, specifically from Business Economics and Industrial Organisation, and is linked to the concepts of value chain and competitiveness. By contrast, the notion of the district emerged from the fields of Development Economics, Applied Economics and Economic Politics.

4. The cluster concept looks at how businesses compete between locations, and at the choices made by multinationals when locating in a territory. The district concept focuses on a territory's evolving capacity to adapt to the competitive environment.

In our opinion, it is the district perspective that most closely aligns with the emergence and evolution of olive growing in Jaén, as this concept seeks to understand how a territory responds to the overall logic of the market using all manner of resources. These include social, economic, cultural and natural resources but with particular emphasis on the interaction between the socio-cultural element and businesses. Thus the business activity of the territory can been understood as the consequence of local societal behaviour, historically borne out of a response to the changes undergone within the olive growing industry and in the international and sectorial environment. The district is, then, above all, a stable community of producers that has opened up a space for itself in the international division of labour while maintaining its lifestyle [38].

It was in light of these distinctions that the Junta de Andalucía [30] sensed the need to look at the issue of olive growing in Andalucía and Jaén from a territorial perspective. This affirmed the olive crop as being much more than simply an agrarian issue, with it becoming the defining element in the make-up of the social, cultural and environmental network of a great many municipalities throughout Andalucía and Jaén. Olive growing is far from being merely a production sector devoted to the extraction of the raw material, its transformation and its commercialisation by external agents largely removed from the modus operandi of its cultivation and its human 'biography'. Olive growing and associated industries form both the backbone and the 'glue' of the rural environment from which they operate, based as they are on a powerful underlying associative movement.

Thus, for the olive oils sector to be properly characterised, an integrative approach is required that takes into account all of its components. Moreover, it is important not to overlook the internal dynamics of the sector itself. These ranged from innovations that embrace the management and design of the olive grove plots and the various farming systems, the gradual growth in prestige of new products and services (taking advantage of residual biomass, environmental and cultural management, and so on), and the modernisation of the industry (efficiencies in process, residue management, a 'quality' approach), to the continual emergence of new commercialisation channels.

Just as with the industrial district, the key factors are competition and cooperation. Competition, very much frontof-mind amongst all local business owners, stimulates continuous improvement and provides the motivation to innovate and adapt to the operating environment. Meanwhile cooperation, fostered by proximity and the in-depth knowledge shared by all businesses in the territory, offers the potential to acquire production factors tailored at a lower cost or with greater quality to the needs of each business.

The cooperative elements help to coordinate the division of labour and contribute to the integrity of the system overall, whilst competitive forces ensure the system remains flexible and innovative [39]. This systemic structure is related to the feeling of belonging to a community, with common interests amongst workers and business owners, and with the existence of cultural mechanisms that transmit marketing knowledge, codified knowledge, and above all contextual knowledge, throughout the network. Contextual knowledge is that which can only be acquired at districtlevel. In this sense the district becomes the setting for collective learning [3], in which knowledge has been transmitted from generation to generation throughout the centuries, and merges with the technological, political and social innovations that arise in each historical era.

This cultural process is a key ingredient in understanding how districts and decision-making processes work. Old institutions compete with new ones for the lead role in the local development process [40], and both influence the thinking of producers from the olive groves, but also that of policy makers, entrepreneurs from other sectors, and other local leaders, because at some level they are all the result of the historical, socio-economic and cultural trajectory of the territory in which they go about their business. In this sense, the local population shares a significant cognitive, social and institutional proximity.

The theory of proximity [41] sets out different forms of territorial organisation amongst businesses, in line with criteria related to both geographical and organisational proximity. In these terms, the olive grove district shares both types of proximity as it bases its development on the same shared 'reality', within one shared territory. This theory upholds cooperation and competition as key, but also expressly includes the external environment, referring to proximity in the sense of being in line with production (that is, organisational) relationships, which can also be established with businesses that belong to the olive oils cluster world-wide and that are geographically distant but organisationally close. This theory also highlights those relationships characterised by physical proximity and organisational distance, such as, for instance, where activities are geared more towards financial management or the retail commercialisation that some players in the agridistrict are moving towards, far from the overall dynamic of activity within the territory.

Furthermore, Boschma [42] points out that while there are advantages to sharing close geographical and organisational proximity as regards competitiveness and productivity of the sector, it can also pose serious drawbacks if that proximity exceeds certain limits. For example, in sharing the same line of thinking and the same organisational, social and institutional approach, they effectively reject ideas from other milieu beyond the district, from a global or strategic perspective, that attempt to undertake activities with fresh dynamism, to offer new solutions to old problems or to avoid problems surfacing in the future. When this happens - as could be the case in Jaén with the commercialisation of the product - the district 
experiences an institutional deadlock that effectively makes it impossible to develop the activity effectively in a world that has already changed.

By way of contrast, new proposals associated with olive growing and related activities in the district are beginning to emerge. Amongst these are proposals for exploiting new byproducts in the renewable energy field, and new rural tourism activities. In this sense, as affirmed by Long and Van der Ploeg [43], the institutions and values of the territorial context are of enormous economic importance, but must not lead to economic and cultural 'shut-down' but rather, on the contrary, should equate to a skilful response to economic challenges by means of specific measures for innovating which, even when they arise from outside, can be tailored and reorganised in line with the ways of the local social culture. Thus, the system is able to regenerate and strengthen itself with new institutions and values that in turn introduce new services and products [44], such as marketing, innovation and development, financing services and so on, all of which, in the case of the Jaén olive growing district, is leading to the arrival of new players, as described in the next section.

As we have seen, the concept of the agri-industrial district is a useful construct for understanding the evolution of olive growing production activity in Jaén. Using this concept we can undertake an analysis of the potential for development in relation to the international olive oils cluster. In the next section we provide an outline characterising the different agents that make up the cluster and implications for the evolution of the district.

\section{THE OLIVE GROWING AGRI-INDUSTRIAL DISTRICT IN JAÉN AND ITS ROLE IN THE OLIVE OILS CLUSTER}

In Fig. (1) we outline the complex network of commercial exchanges or channels, by means of which the organisations and agents that make up the olive oils cluster inter-relate. As can be seen, alongside the primary sector/olive oils sector, and moving up the value chain, are a series of industries that are inter-connected whilst having different characteristics - namely those involved with the initial grinding phase of production, the refineries, the pomace extraction plants, and bottling companies. Furthermore, some of these organisations cover several functions within the production-consumption chain.

The last decade has witnessed diversification within the cluster, with new players who, attracted by the increased demand for products related to the Mediterranean diet and the use of olive oils, are establishing new 'emerging activities' which are having a noticeable influence on the agri-district. Hence we can speak of concentric diversification operating in four directions:

1. Food industries, and producers of tinned fish, cakes and pastries, cold meats and sausages, and meat products.

2. Cosmetic and even pharmaceutical industries that are using olive oils in developing their products as a result of the widespread recognition of the health benefits of consuming olive oils.
3. Industries operating on the back of by-products and waste products from the olive grove and olive oils, thanks to which such products increase in value. Examples include: pomace; orujillo ${ }^{7}$; and olive stones and materials left over from the pruning process which are used to produce thermal and electric energy, pellets ${ }^{8}$ and bioethanol, and in industries working with active carbon, enzymes, and so on.

4. Services related to positively valuing olive-growing heritage, from an environmental and cultural perspective. Tourism, gastronomy and educational leisure activities can provide the agri-district with a new profit dimension of high value-added, within a long-term strategy. Amongst the most notable examples where new development possibilities are being initiated is the La Laguna Museum.

In addition to this network of industries and new services, and downstream in the value chain, there are also businesses providing machinery, equipment and other facilities for cultivating olive groves and producing olive oils. Many of these are located in Jaén province or, if not, have an extensive distribution network in the territory. As well as these organisations, the cluster also contains, logically, the Olive Oils Futures Market (MFAO), and commercial distribution.

However, before analysing the sectorial structure and the behaviour of the different agents, it would be helpful to make clear that the olive oils cluster in Jaén takes the form of an industrial agri-district as it established as a cooperative movement of farmers. From a commercial point of view, cooperative olive oil mills generally focus on turning the olives produced by their members into oils, and then selling the majority of their produce unbottled and in bulk to major refining and/or packaging companies which operate in the market from a different perspective. So it is that, despite the recent appearance of shared points of sale, cooperativeproduced olive oils are still rarely seen in bottled oils sales channels. This scenario within the agri-district has been labelled the 'commercialisation problem'. Overcoming this issue is a key objective for both public administration bodies and private agents, with the ultimate aim of achieving greater impact for the olive oils production industry on income, employment and wealth in the provincial territory. This gives rise to a degree of institutional 'tension' between the traditional ways of the agents operating in the agri-district, and the efforts of the public bodies and some local agents who are attempting to create new institutions more focused on the end-market. However, the main role adopted by local farmers and local mill owners in the world olive oils cluster is that of provider to the intra-industrial market, with a minimal presence in the end-market.

On the other hand, it is worth noting that as well as the economic importance of being a key player in the economy and society of Jaén, given the new functions that society is demanding of the rural environment - and bearing in mind the profoundly territorial nature of agrarian activity - the district must be regarded as a core plank of development in the territory. It is also a provider of certain goods and public

\footnotetext{
${ }^{7}$ Residue left over following extraction of the pomace, for use in fuels.

${ }^{8}$ Small pieces of dried wood used for domestic fuel.
} 


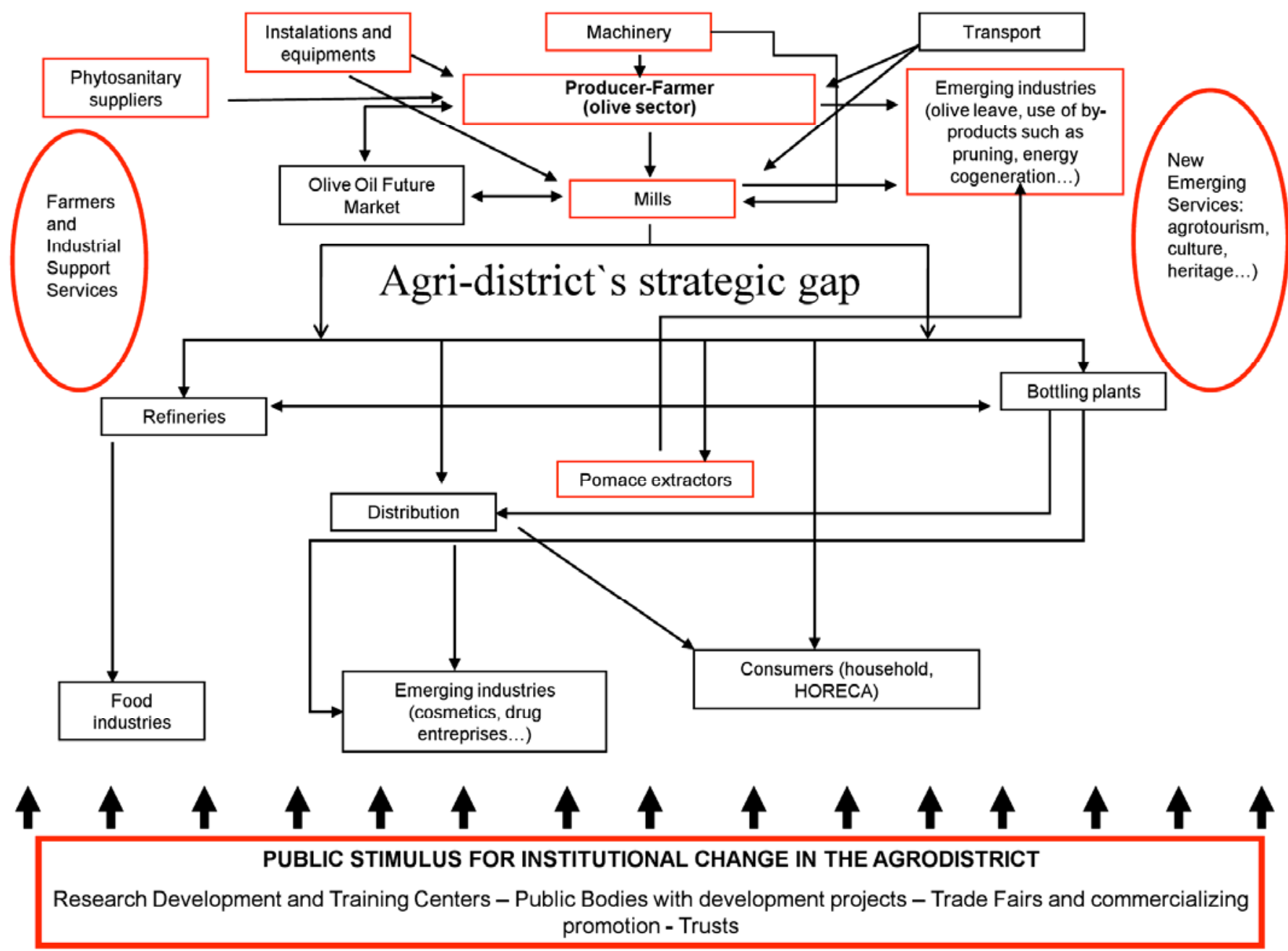

Fig. (1). Diagram of the olive oils cluster (activities with the greatest prevalence in the agri-district are marked in red). Source: In-house compilation.

services, such as preservation of the environment, conservation of natural spaces, protection of biodiversity, and upholding of rural culture, the landscape and family-run enterprises. In the environmental sphere, olive groves can play an essential role in climate change, on three fronts: by limiting the emission of greenhouse-effect gases; promoting carbon confiscation on the ground; and producing renewable, sustainable energy. These activities are effective strategies for the province of Jaén, embracing its social, environmental, cultural and economic aspects. These strategies extend out to society as a whole, both in Europe and world-wide, as the benefits they create go far beyond the territory where they are carried out. They should therefore be reflected in public sector planning for activities that support the agri-district, within the framework of the Common Agricultural Policy and the Rural Development Policy in forthcoming years.

The fact that for public bodies this activity in the territory is of strategic importance has led to a marked drive to implement different activities, with public and private participation and with unquestionable public backing at regional and provincial level. Amongst such activities, we highlight the following:

1. In the promotional realm, the well established International Olive Oils and Associated Industries
Fair (Feria Internacional del Aceite de Oliva e Industrias Afines, or EXPOLIVA) ${ }^{9}$. This brings together the key players in the world-wide sector, and although its principal focus is still, in market terms, the farmer as client, it provides a major meeting point for producers and distributors of the different products and services that are delivered throughout the cluster's value chain. The Fair also enables the agri-district to have a direct connection with the key technological innovations emerging world-wide in the different spheres of production, and facilitates the introduction of new ideas. In such a way, even the more conservative players are presented with new forces for change.

2. In the field of information and commercial transactions, the creation of the Olive Oils Futures Market (MFAO) ${ }^{10}$. Its fundamental mission is to offer more, and better, information on the olive oil pricing process, information that until recently was basically in the hands of the major distributors, who made their 'buy' offers with an unfair information advantage,

\footnotetext{
${ }^{9}$ See http://www.expoliva.com

${ }^{10}$ See http://www.mfao.es
} 
with the corresponding losses for sellers of unbottled oils -that is, the majority of sellers from the agridistrict. However, there are no industrial members from the territory in this market.

3. The area of training, research and knowledge transfer is where the most significant developments have taken place in recent years, with the creation of different bodies devoted to strengthening the competitive capacity of the agri-district and improving its position in the world-wide olive oils cluster:

1.1. The creation of the Olive Grove and Olive Oil Science and Technology Park (Parque Científico-Tecnológico del Olivar y del Aceite de Oliva, or GEOLIT) ${ }^{11}$, has brought with it an infrastructure that seeks to bring together the most innovative players from those industries and services most closely linked to the activities of the agri-district, and a platform for creating economies of agglomeration to stimulate innovation amongst its agents.

1.2. The Olive Grove and Olive Oil Technological Centre (Centro Tecnológico del Olivar y el Aceite, or CITOLIVA) ${ }^{12}$, whose mission is to stimulate and develop projects designed to facilitate the innovation and change process in the agri-district. It also promotes these projects throughout the value chain, with a particular focus on improving competitiveness amongst local and regional agents.

1.3. The 'Venta del Llano' Agrarian Research and Training Centre (Centro de Investigación y Formación Agraria "Venta del Llano"). With over 100 years' experience in the territory, it is currently one of the most well respected research and training centres in the world. It is primarily devoted to studying and improving production processes and delivering training courses related to olive growing and olive oils.

1.4. Activities undertaken by the University of Jaén. This institution has wide-ranging research experience in different aspects of the cluster, and teaching-wise it offers a range of specialist studies, such as, for instance, the Masters programme in the Olive Grove, Olive Oil and Health, and the international postgraduate programme in Virgin Olive Oil Tasting.

1.5. Beyond the agri-district that we are describing, but with a strong and lasting connection to it (with high organisational proximity), the olive oils cluster has the International Masters in Olivegrowing and Oil Technology which is delivered by the University of Cordoba (situated less than $60 \mathrm{~km}$ from Jaén province). There are also several different research activities undertaken on behalf of the sector by

\footnotetext{
${ }^{11}$ See http://www.geolit.es

${ }^{12}$ See http://www.citoliva.es
}

the National Council for Scientific Research (Consejo Superior de Investigaciones Científicas).

\subsection{Sectorial Structure and Behaviour}

\subsubsection{Primary Sector: Olive-Growing Sector}

According to Spain's Ministry for Rural Affairs, olive groves devoted to olives for making oils cover some 2,299,322 hectares nationally [45]. This area represents over $30 \%$ of the world-wide total, and $46 \%$ of that in Europe overall [30]. Andalucía, which accounts for $61 \%$ of the national area, is the largest olive-growing region of Spain. At provincial level, Jaén, with $25 \%$ of the national area, $40 \%$ of the Andalucían area and $7.5 \%$ of the world-wide area, is the largest olive-growing province in the world.

Meanwhile in Andalucía there are 295,539 olive groves devoted to growing olives for oil, of which some 140,641 (48\%) are located in Jaén province [30]. This fact highlights a key characteristic of the agri-district: the small scale of its olive groves (4 hectares). Likewise, in Jaén province the olive grove of traditional layout is the most predominant, with an average plot density of 117 trees per hectare, far lower than that of Almería and Seville, with 173.7 and 163.2 respectively. It also differs greatly from the Andalucían average of 130.3 trees per hectare [30]. This data clearly reveals the predominance of the traditional olive grove in Jaén province, where there are very few intensivelycultivated olive groves (200-550 olive trees per hectare) or super-intensively cultivated (2,000 trees per hectare). These are much more productive, easier to mechanise and therefore much more profitable. However, it must be noted that, presently, Jaén's olive groves are the most productive in Andalucía, whether irrigated or not. Thus, while the average production-per-hectare of olives in Andalucía stands at $3,431 \mathrm{~kg}$ (unirrigated) and $4,451 \mathrm{~kg}$ (irrigated), the averages in Jaén province are $3,789 \mathrm{~kg}$ and $5,056 \mathrm{~kg}$ respectively.

A further fundamental characteristic of the agri-district is the practice of part-time agriculture. According to the year 1999 Agrarian Census some $41 \%$ of olive grove owners undertake other income-generating activities beyond olive cultivation, which is the second sector after fruit and citrusgrowing for having the greatest incidence of owners dedicated to other activities. Of this $41 \%$, for $88 \%$ the 'other activity' is the main one. Equally in the olive-growing sector around $85 \%$ of owners employ fewer than $0.25 \%$ of units of work per year in their olive-growing activities, with barely $2.5 \%$ of owners using more than one unit of work per year. This situation helps to explain, in part, the small scale of most olive grove exploitation and the concentration of tasks at specific times of year (during the harvest). Finally, it is worth highlighting a further defining characteristic, namely the increasing age of farmers, with $71.5 \%$ of olive grove owners being above 45 years of age, and $28 \%$ above $64 \%$ [30].

In the realm of business associativism, there are four agrarian organisations in Jaén province that represent and defend the interests of olive producers. These are: the Asociación Agraria de Jóvenes Agricultores (ASAJA), the Unión de Pequeños Agricultores y Ganaderos (UPA), the Coordinadora de Organizaciones de Agricultores y 
Ganaderos (COAG) and the Federación de Agricultores y Ganaderos de Jaén (UDOE-ASAGA). The first three operate at national level and bring together, represent and defend the interests of all agricultural and livestock professionals in Spain, from different ideological perspectives. UDOEASAGA is focused exclusively on olive growing and specifically in Jaén province. The first three organisations participate in all the various forums for dialogue at local, regional, national and international level. An example of one such forum is the Comite de Organizaciones Profesionales Agrarias de la Unión Europea (COPA), in which all activities within the Framework of the Common Agricultural Policy are debated, and which puts forward proposals as appropriate to the European Commission and the Council of Ministers of the European Union. In summary, then, the role played by these four organisations, at varying levels and to varying degrees, is decisive in the process of modernisation and advancement in Jaén's olive oils sector.

\subsubsection{Industrial Sector: Production, Production Structure and Commercial Behaviour}

Tables $\mathbf{1}$ and $\mathbf{2}$ show the evolution of olive oil production during the last 20 years, both world-wide and in the
European Union (EU), as well as in Spain. As can be seen, production has followed an upward trend, and this is as a result of two fundamental factors: the increase in the area covered by olive groves, and the technological improvements witnessed in cultivation, above all in irrigation.

Considering how important the EU's production is relative to world production levels (accounting for approximately $75 \%$ ), the evolution of production world-wide and that of the EU share a physiognomy that is practically identical. As a result, growth in world production levels is due largely to growth in Spain. Other countries with significant levels of production, as well as Italy and Greece, are Tunisia, Syria, Turkey, Morocco and, to a lesser degree, Algeria and Portugal.

Spain produces around $40 \%$ of olive oils in the world, and 55\% of olive oils in the EU. Within Spain itself, Jaén province, producing on average some 500,000 tonnes per harvest [45], is the oils-producing territory bar none, with a world-wide market share of $18 \%$, a European market share of $24 \%$, and $45 \%$ within Spain, which is the number one olive oils producer in the world.

Table 1. Evolution of Olive Oils Production World-Wide (in Thousands of Tonnes)

\begin{tabular}{|c|c|c|c|c|c|c|}
\hline \multirow{2}{*}{ Country } & \multicolumn{6}{|c|}{ Harvest } \\
\hline & $1990 / 91$ & $1994 / 95$ & $1996 / 97$ & $2003 / 04$ & $2008 / 09 *$ & $2009 / 10 * *$ \\
\hline Albania & No data & No data & No data & No data & 5.50 & 13.00 \\
\hline Argentina & 8.00 & 6.50 & 11.50 & 13.50 & 23.00 & 16.00 \\
\hline Algeria & 6.00 & 16.50 & 50.50 & 69.50 & 59.00 & 50.00 \\
\hline Australia & No data & No data & No data & 2.50 & 16.00 & 18.00 \\
\hline Chile & No data & No data & No data & No data & 8.50 & 8.50 \\
\hline Croatia & No data & No data & No data & 3.00 & 6.00 & 5.50 \\
\hline Cyprus & 2.00 & 3.00 & 2.00 & No data & No data & No data \\
\hline Egypt & 0.50 & 1.00 & 0.50 & 2.00 & 5.00 & 2.00 \\
\hline $\mathrm{EU}$ & 994.00 & $1,371.00$ & $1,754.50$ & $2,448.00$ & $1,993.00$ & $2,148.50$ \\
\hline Iran & 0.50 & 1.50 & 1.50 & 2.50 & 4.50 & 3.00 \\
\hline Israel & 8.00 & 5.50 & 5.50 & 3.00 & 8.00 & 3.50 \\
\hline Jordan & 8.00 & 13.50 & 23.00 & 25.00 & 18.50 & 27.50 \\
\hline Lebanon & 6.00 & 5.00 & 6.50 & 7.50 & 24.50 & 9.00 \\
\hline Libya & 7.00 & 6.50 & 10.00 & 12.50 & 15.00 & 15.00 \\
\hline Montenegro & 3.50 & 2.50 & 0.50 & 0.50 & 0.50 & 0.50 \\
\hline Morocco & 36.00 & 45.00 & 110.00 & 100.00 & 85.00 & 95.00 \\
\hline Palestine & No data & 82.00 & 12.00 & 5.00 & 20.00 & 5.50 \\
\hline Saudi Arabia & No data & No data & No data & No data & 3.00 & 3.00 \\
\hline Syria & 83.00 & 90.00 & 125.00 & 110.00 & 130.00 & 150.00 \\
\hline Tunisia & 175.00 & 100.00 & 270.00 & 280.00 & 150.00 & 140.00 \\
\hline Turkey & 80.00 & 160.00 & 200.00 & 79.00 & 130.00 & 147.00 \\
\hline USA & 1.00 & 1.00 & 1.00 & 1.00 & 2.50 & 3.00 \\
\hline TOTAL & $1,453.00$ & $1,845.50$ & $2,595.00$ & $3,174.00$ & $2,665.50$ & $2,881.50$ \\
\hline
\end{tabular}

*Provisional data

**Forecast.

Source: [46]. In-house compilation. 
Table 2. Evolution of Olive Oils Production in the EU (in Thousands of Tonnes)

\begin{tabular}{|c|c|c|c|c|c|c|}
\hline \multirow{2}{*}{ Country } & \multicolumn{6}{|c|}{ Harvest } \\
\hline & $1990 / 91$ & $1994 / 95$ & $1996 / 97$ & 2003/04 & $2008 / 09 *$ & $2009 / 10 * *$ \\
\hline Cyprus & 2.00 & 3.00 & 2.00 & 7.00 & 3.50 & 5.00 \\
\hline $\mathrm{EU}$ & 993.70 & $1,371.00$ & $1,754.50$ & $2,448.00$ & $1,993.00$ & $2,148.40$ \\
\hline France & 1.00 & 2.00 & 2.50 & 4.60 & 7.00 & 5.00 \\
\hline Greece & 170.00 & 350.00 & 390.00 & 308.00 & 305.00 & 348.00 \\
\hline Italy & 163.30 & 448.00 & 370.00 & 685.00 & 540.00 & 540.00 \\
\hline Portugal & 20.00 & 32.20 & 44.80 & 31.20 & 49.00 & 50.00 \\
\hline Slovenia & No data & No data & No data & 0.20 & 0.50 & 0.40 \\
\hline Spain & 639.40 & 538.80 & 947.30 & $1,412.00$ & $1,028.00$ & $1,200.00$ \\
\hline TOTAL & $1,453.00$ & $1,845.50$ & $2,595.00$ & $3,174.00$ & $2,665.50$ & $2,881.50$ \\
\hline
\end{tabular}

*Provisional data

**Forecast.Source: [46].

In-house compilation.

In Spain there are some 1,738 olive oils mills, of which 821 are in Andalucía and, of these, 327 are in Jaén province [47]. Those mills that are owned and operated cooperatively represent $54 \%$ of the total $[48, \mathrm{p} .13]$ and produce $70 \%$ of the national production total. This means that cooperative organisations - the great majority of producers in the agridistrict - enjoy a high level of involvement in the olive oils market, such that their collective behaviour determines to a large extent the future of the entire olive oils cluster.

As we highlighted in referring to the so-called 'commercialisation problem', cooperative olive oil mills operate, in the main, within the bulk unbottled (intraindustry) market and very little within the bottled (end-) market. They tend to focus on transforming the olives produced by their members into oils, selling most of them unbottled and in bulk to the major refining or bottling companies that operate within the market, and selling small quantities directly to other members (auto-consumption) or in the local market. Thus, in line with the work of Torres et al. [49, pp.42-43], in the 1997-98 harvest, independent or first-tier cooperative mills commercialised $8.70 \%$ of production (bottled), and second or third-tier cooperatives (that is, those composed of other cooperatives) commercialised $9.30 \%$. In both groups, over $85 \%$ of the oils bottled were for members' own consumption $-86.8 \%$ for second or third-tier cooperatives and $89 \%$ for independent ones. Second and third-tier cooperatives put around $12 \%$ of their production in the hands of distributors, and the independent cooperatives, some $9.9 \%$.

On the other hand, the sale of oils to Italian operators is also very common. They systematically acquire Spanish virgin olive oils of exceptional quality and then use them in Italy, either for commercialisation following bottling, or for 'encabezado' (mixing) with refined oils to produce the 'Riviera' type Italian oils (the equivalent of Spanish 'olive oil'). In this sense, it is worth noting that Spain commercialises over 600,000 tonnes of oil in foreign markets, with Italy being traditionally the country with the highest consumption of Spanish oil (at approximately 400,000 tonnes per year on average), followed by France,
Portugal, United States, United Kingdom and Australia. In the main, it is unbottled oils that are sent to the Italian market, whilst bottled oils predominate in the United States, Japan and Australia. In either case, bottled oils account for only $25 \%$ of all oils commercialised.

Despite their lead position in the world market by volume, Spanish oils in general, and oils from Jaén province in particular, do not figure prominently (barring the odd exception) in retail establishment listings from the new consumer countries such as the United States, Australia or Saudi Arabia, and indeed they lack a quality image. By contrast, it is the Italian oils that enjoy greater prestige and positioning in these markets. Overall, then, the agri-district's exportation model reveals the same weakness as the national model, in focusing on selling unbottled oils in bulk. As well as limiting the scope for greater value-added, this focus also makes it impossible to take full advantage of the benefits of active participation in the internationalisation process. Such benefits include greater professionalisation in the sector, better use of resources thanks to lower average costs, and the ability to specialise and generate a country 'brand image' abroad. On this latter point, Italian-brand olive oils enjoy a much more positive image to the extent that there are countries where olive oil is associated exclusively with Italy and not with the world's largest producer and exporter.

In this context, there can be said to be scant participation by Jaén-based firms in foreign olive oil trade as they take a passive stance to foreign commercialisation - as demonstrated by their lack of presence in the Spanish Association for the Olive Oil Industry and Export Trade (Asociación Española de la Industria y el Comercio Exportador del Aceite de Oliva, or ASOLIVA ${ }^{13}$ ). This Association is made up of 59 exporters whose sales outside of Spain represent over $95 \%$ of the bottled olive oils exported nationally, and between $50 \%$ and $75 \%$ of the unbottled olive oils exported. Only one Jaén-based firm belongs to the Association, compared to 13 from Seville, and 10 from Córdoba.

\footnotetext{
${ }^{13}$ See http://www.asoliva.es
} 
In short, the cooperative movement within the olive oils cluster is of particular importance during the phase of production that relates to transforming olives into oils, and it is organised via the Andalucían Federation of Agrarian Cooperatives (Federación Andaluza de Empresas Cooperativas Agrarias, or FAECA ${ }^{14}$ ). However, although cooperatives dominate the production of virgin olive oils, except in a few limited cases, their gravitas in the market is not even close to their production potential. Furthermore, although it is true to say that we are beginning to see a change of attitude in how cooperatives operate, in general they are still far from having a philosophy that is orientated towards the end-market.

In the case of private industrial mills, in the main these operate in the same way as cooperative mills and they also have a national organisation (based in Jaén) which represents and defends their interests - the Spanish Federation of Olive Oil Producers (Federación Española de Industriales Fabricantes de Aceite de Oliva, or INFAOLIVA ${ }^{15}$ ).

The refineries undertake both olive oil refining and also production of pomace and seed oils. Normally, bottling companies operating as medium or large-size businesses have their own refineries. In Spain there are 25 refineries, in the main trading companies, 16 of which are in Andalucía and 5 in Jaén province. There is little associativism seen in this aspect of production, as a result of which producers of virgin olive oils generally are not interested in obtaining 'olive oil', a stance which is undoubtedly influenced by how they view their function in the market, namely to see themselves as only producers of unbottled olive oils [47].

Meanwhile there are some 60 olive pomace extraction factories in Spain, 37 of which are located in Andalucía, and 17 in Jaén.

As regards the major refining and bottling companies, these bottles are other types of oils as well as olive oils. Generally, they buy virgin oils from the mills and refined oils from third parties outside the district if they do not have their own refineries, which is typically the case. In the bottling plants, they either bottle edible virgin olive oils, or they make up the 'encabezado' - the mixture - with refined oil to produce 'olive oil', the most widely-consumed in Spain. They then take the products to consumers via the commercial distribution sector, which we shall refer to later. In Spain there are in the region of 1,522 bottling companies and operators ${ }^{16}$ [47]. Bottling companies can be classified into four main categories: those belonging to major oilproducing firms or groups which are the largest concerns and bottle the entire range of oils; bottling companies that are integrated into mills which, in turn, can be classified into two sub-types, larger and smaller; bottling companies that belong to major distributors; and independent companies that bottle all types of oils. It is estimated that $60 \%$ of bottling companies in Spain are integrated within mills, although because of their small size they only account for $22 \%$ of the total bottling capacity.

\footnotetext{
${ }^{14}$ See http://www.faeca.es

${ }^{15}$ See http://aceiteyolivos.com/infaoliva

${ }^{16}$ The operators acquire oils, store them and then place them in the market when the timing is right. Although their core activity centres on buying and selling oils unbottled, they also operate in the bottling market.
}

The major bottling companies that operate not only in Spain but also on a world-wide scale are: the SOS Group, Sovena, the Acesur Group, the Ybarra-Migasa Group and the Hojiblanca Group. Of these, only the Hojiblanca Group is a cooperative. It is worth highlighting the absence of Jaénbased cooperatives from amongst the key players in the oil bottling market, with the exception of Olivar de Segura which is lower down the ranking. It is true to say, however, that some Jaén-based cooperatives have been integrated into the Hojiblanca Group, and that Aceites Coosur, located in Jaén, belongs to the Acesur Group. Also the SOS Group has facilities in the province, and Oleo Martos is a local noncooperative firm ranked amongst the top ten bottling companies. On the other hand, it must be noted that Sovena is a company that only commercialises distributor brands, something we shall refer to later on.

It remains true, however, that cooperative firms from the agri-district are thin on the ground within the bottled oils market. This confirms once more what we refer to as the 'commercialisation problem', that is, the distancing of the cooperative movement from the end-market - a symptom of poor end-market orientation amongst famers, who prefer to also manage the industrial phase of the cluster's value chain.

All the major bottling companies, with the exception of the Hojiblanca Group, belong to the National Association of Edible Oils Bottling and Refining Industries (Asociación Nacional de Industriales Envasadores y Refinadores de Aceites Comestibles, or ANIERAC ${ }^{17}$ ). This Association is made up of 85 firms, of which 10 are based in Jaén province.

\subsubsection{Consumption and Distribution of Olive Oils}

The most extraordinary feature of the evolution of the olive oils market in recent years is the tremendous increase in demand. In fact, as can be seen in Table $\mathbf{3}$, during the last 19 harvests, world-wide consumption of olive oils has doubled. The key to this spectacular growth is, on the one hand, demand-led behaviour in the EU, where as a region overall consumption has increased by approximately 750,000 tonnes and, on the other hand, demand amongst a group of countries where the growth in consumption has been even greater than in the EU. Here we are referring mainly to Brazil, Australia, Canada, Japan, Russia and the United States. The latter, with a forecast consumption of 260,000 tonnes in 2009-10, is in third place, in absolute terms, behind Italy and Spain.

In addition to these countries, others registering significant levels of consumption are: Syria, with consumption at 120,000 tonnes, a slight increase; Algeria, with consumption close to 50,000 tonnes (although despite showing a growth trend, the figures also reveal major highs and lows depending on the harvest); Morocco, with consumption at 70,000 tonnes, showing a slight upward trend and with greater stability in the figures from one season to the next than Algeria; Tunisia, with a consumption of 35,000 tonnes, representing a slight drop; and Turkey, where consumption stands at 100,000 tonnes and where the market is on the up. As well as these countries, all of them producers, there are other countries where the evolution in consumption has been significant in relative terms, but

\footnotetext{
${ }^{17}$ See http://www.anierac.com
} 
Table 3. Evolution of World-Wide Consumption of Olive Oils (in Thousands of Tonnes)

\begin{tabular}{|c|c|c|c|c|c|c|}
\hline \multirow{2}{*}{ Country } & \multicolumn{6}{|c|}{ Harvest } \\
\hline & $1990 / 91$ & $1995 / 96$ & $1996 / 97$ & $2004 / 05$ & 2008/09* & $2009 / 10 * *$ \\
\hline Algeria & 7.00 & 36.00 & 50.00 & 38.00 & 59.00 & 50.00 \\
\hline Australia & 13.50 & 16.50 & 21.50 & 32.50 & 37.00 & 37.50 \\
\hline Brazil & 13.50 & 19.00 & 24.50 & 26.50 & 42.00 & 42.50 \\
\hline Canada & 10.00 & 14.00 & 19.00 & 32.00 & 17.00 & 17.00 \\
\hline $\mathrm{EU}$ & $1,214.50$ & $1,387.00$ & $1,566.50$ & $2,079.00$ & $1,854.50$ & $1,856.50$ \\
\hline Israel & 6.00 & 7.50 & 7.50 & 16.00 & 16.00 & 16.50 \\
\hline Japan & 4.00 & 16.50 & 26.00 & 32.00 & 29.50 & 29.50 \\
\hline Jordan & 9.50 & 16.00 & 22.00 & 25.00 & 23.50 & 29.50 \\
\hline Morocco & 37.00 & 25.00 & 50.00 & 38.00 & 70.00 & 70.00 \\
\hline Russia & 5.00 & 1.00 & 1.50 & 9.00 & 17.50 & 18.00 \\
\hline Syria & 62.00 & 78.00 & 85.00 & 135.00 & 110.00 & 120.00 \\
\hline Tunisia & 54.50 & 34.50 & 70.00 & 44.00 & 35.00 & 35.00 \\
\hline Turkey & 55.00 & 63.00 & 75.00 & 60.00 & 97.00 & 98.00 \\
\hline USA & 88.00 & 101.00 & 130.50 & 215.50 & 254.00 & 260.00 \\
\hline TOTAL & $1,666.50$ & $1,888.50$ & $2,241.50$ & $2,923.50$ & $2,825.50$ & 2,839.00 \\
\hline
\end{tabular}

*Provisional data.

**Forecast.

Source: [46]. In-house compilation.

where demand in absolute terms is still low - as is the case in Israel, Mexico and Switzerland, for instance.

Looking at how olive oil consumption has evolved in member countries of the EU, it can be deduced that, given the EU's share of world-wide consumption, its trends will be in line with the world-wide picture. As can be seen in Table 4, olive oil consumption in the EU overall has grown significantly in the last two decades and, remarkably, this is the case in almost all EU countries. As regards Spain, national consumption stands at around 560,000 tonnes, mainly accounted-for by 'olive oil' as opposed to edible virgin oils.

With regard to the extraordinary growth in demand as described above, the increase in the concentration of businesses in commercial distribution, together with the growth in market share of distributor brands, the two being related, are turning into key change factors in the development of the olive oils cluster. In fact, the process of increasing concentration in the commercial distribution sector - provoked by mergers, acquisitions, the creation of central purchase and service points, and so on - has brought about greater asymmetry in bargaining power amongst the major distributors in the cluster and the agri-district. In this sense, we believe that the trend towards greater domination by the major distribution channels and the increase in market share amongst distributor brands will make it more difficult for producers to access the bottled oils market, unless they change their current strategy and re-focus, from production orientation to market orientation (MO).

The two factors we have referred to are decisive for the design of business strategies in the olive oils sector. This is due to the fact that, as can be seen in Table $\mathbf{5}$, most olive oils sales $(85.68 \%$ for olive oils and $82.88 \%$ for edible virgin olive oils) occur in self-service establishments, a far cry from the situation ten years ago with regard to virgin olive oils. In fact, in 1999 around $50 \%$ of the total value of purchases of virgin olive oils made by households was accounted-for by formats other than the classic commercial channels: 'cooperative olive oils mills' (26.70\%), 'purchased direct from the producer' (19.80\%), and 'for own consumption' $(6.20 \%)$. It is these results that led us to believe that there was a major deficit in the commercialisation of virgin olive oils, to the extent, we said, that commercialisation of olive oils followed a 'conventional' model, whilst that of virgin and extra virgin olive oils was 'rural' or 'agrarian' [50]. Clearly the data presented in Table $\mathbf{5}$ - which is in line with data on the evolution of virgin olive oils consumption in Spain - underlines the fact that these products are present in the distribution channels that the Spanish use for their food purchases. This is the ideal way for demand to continue to rise, and is thanks in large part to the efforts of the production sector (in which the Jaén province agri-district has played an important role), and its presence in the bottling market, albeit this presence is still far from sufficient.

Next, Table $\mathbf{6}$ shows how market shares evolved amongst the key foodstuffs distribution groups in the period 20012006, encompassing total sales of foodstuffs, cosmetics and toiletries, and perfumes. As can be seen, the market share of the four leading foodstuffs distribution groups in Spain grew 
Table 4. Evolution of Olive Oils Consumption in the EU (in Thousands of Tonnes)

\begin{tabular}{|c|c|c|c|c|c|c|}
\hline \multirow{2}{*}{ Country } & \multicolumn{6}{|c|}{ Harvest } \\
\hline & 1990/91 & 1995/96 & 1996/97 & $2004 / 05$ & $2008 / 09 *$ & $2009 / 10 * *$ \\
\hline EU & $1,214.50$ & $1,387.00$ & $1,566.50$ & $2,079.00$ & $1,854.50$ & $1,856.50$ \\
\hline France & 28.00 & 48.50 & 58.80 & 97.10 & 110.10 & 108.80 \\
\hline Germany & 10.30 & 16.40 & 16.10 & 46.30 & 49.50 & 51.40 \\
\hline Greece & 204.00 & 230.00 & 240.00 & 283.00 & 221.10 & 220.00 \\
\hline Holland & 1.00 & 2.30 & 3.50 & 13.40 & 9.30 & 15.00 \\
\hline Italy & 540.00 & 653.00 & 675.00 & 840.00 & 710.00 & 710.00 \\
\hline Portugal & 27.00 & 58.40 & 62.00 & 74.50 & 74.00 & 74.00 \\
\hline Spain & 394.10 & 352.10 & 470.20 & 615.70 & 561.40 & 560.00 \\
\hline UK & 6.80 & 15.00 & 25.10 & 60.10 & 58.30 & 55.50 \\
\hline
\end{tabular}

*Provisional data.

**Forecast.

Source: [46]. In-house compilation.

Table 5. Market Share by Final Distribution of Oils Across Households in 2007 (in Percentages)

\begin{tabular}{|c|c|c|c|c|}
\hline \multirow{2}{*}{ Format } & \multicolumn{4}{|c|}{ Types of Vegetable Oils } \\
\hline & Olive Oils & Sunflower Oils & Virgin Olive Oils & Total Oils \\
\hline Traditional shops & 2.17 & 0.83 & 3.24 & 2.03 \\
\hline Self-service and supermarkets & 36.43 & 39.02 & 34.60 & 37.11 \\
\hline Discount supermarkets & 21.80 & 34.55 & 10.92 & 22.44 \\
\hline Hypermarkets & 27.45 & 23.67 & 37.36 & 29.08 \\
\hline Company stores and consumer cooperatives & 2.18 & 0.34 & 3.54 & 1.92 \\
\hline Door-to-door sales & 0.08 & 0.10 & 0.53 & 0.21 \\
\hline Small local markets & 0.06 & 0.00 & 0.11 & 0.05 \\
\hline For own consumption & 3.69 & 0.00 & 0.78 & 1.84 \\
\hline Rest & 6.14 & 1.49 & 8.93 & 5.32 \\
\hline TOTAL & 100.00 & 100.00 & 100.00 & 100.00 \\
\hline
\end{tabular}

Source: [45]. In-house compilation.

from $48.60 \%$ in 2001 to $55 \%$ in 2006 , a market share that is set to grow, thanks to the Caprabo Group being taken over by the Eroski Group, and Plus Supermercados being taken over by the Carrefour Group ${ }^{18}$.

Looking at the eight leading foodstuffs distribution groups, their market share evolved from $59.50 \%$ in 2001 to $66.50 \%$ in 2006. This data confirms the growth in the concentration of businesses in commercial distribution which is on an upward trend albeit still a long way from the growth witnessed amongst EU countries.

Tables $\mathbf{7}$ and $\mathbf{8}$ show sales and market shares for the leading brands and companies that operate in the Spanish

\footnotetext{
${ }^{18}$ In 2006, the Caprabo Group had a market share of $3 \%$ and Plus Supermercados held $0.90 \%$. As a result, and although the two organisations were acquired in 2007 by the Eroski Group and the Carrefour Group respectively, we can estimate that the market share of the four leading food distribution groups in Spain is in the region of $60 \%$.
}

Table 6. Evolution of Market Shares of the Main Foodstuffs Distribution Groups in Spain, in the Period 20012006 (in Percentages)

\begin{tabular}{|l|c|c|c|}
\hline \multicolumn{1}{|c|}{ Company/Trade Mark } & $\mathbf{2 0 0 1}$ & $\mathbf{2 0 0 3}$ & $\mathbf{2 0 0 6}$ \\
\hline \hline Grupo Carrefour & 24.40 & 23.30 & 23.00 \\
Mercadona & 10.30 & 14.60 & 17.70 \\
Grupo Eroski & 8.30 & 8.30 & 7.50 \\
Grupo Auchan & 5.60 & 6.00 & 5.80 \\
El Corte Inglés (Alimentación) & 3.10 & 3.50 & 3.80 \\
LIDL & 3.20 & 3.50 & 3.40 \\
Grupo Caprabo & 2.50 & 3.30 & 3.00 \\
Ahorramás & - & 1.30 & 1.30 \\
\hline
\end{tabular}

Source: [51, p.143].

bottled olive oils market. As can be seen, it is the own-brand distributors that collectively take the lead in the Spanish 
Table 7. Olive Oils Market. Sales and Market Share by Groups and Brands in Spain in 2004

\begin{tabular}{|c|c|c|c|c|}
\hline \multirow{2}{*}{ Groups } & \multicolumn{2}{|c|}{ Olive Oils } & \multicolumn{2}{c|}{ Virgin Olive Oils } \\
\cline { 2 - 5 } & Sales (in Thousands of Litres) & Market Share (\%) & Sales (in Thousands of Litres) & Market Share (\%) \\
\hline \hline $\begin{array}{c}\text { Distributor Brands } \\
\text { SOS Group } \\
\text { (Koipe, Carbonell, Salgado and Elosúa) }\end{array}$ & 113.002 & 52.45 & 23.911 & 37.77 \\
\hline $\begin{array}{c}\text { Ybarra-Migasa Group } \\
\text { (La Masía, Ybarra, Mueloliva, } \\
\text { Minerva and Rafael Salgado) }\end{array}$ & 50.554 & 23.47 & 6.262 & 9.89 \\
\hline Acesur Group (Coosur and La Española) & 16.586 & 7.72 & 339 \\
\hline $\begin{array}{c}\text { Hojiblanca Group } \\
\text { (Hojiblanca, Cordoliva and Torcaoliva) }\end{array}$ & 13.843 & 6.41 & 2.362 & 11.971 \\
\hline Rest & 21.453 & & 3.73 \\
\hline TOTAL & 215.438 & 9.95 & 18.463 \\
\hline
\end{tabular}

Source: [53].

Table 8. Olive Oils Market. Sales and Market Share by Groups and Brands in Spain (March 2008-March 2009)

\begin{tabular}{|c|c|c|c|c|}
\hline \multirow[b]{2}{*}{ Groups } & \multicolumn{2}{|c|}{ Olive Oils } & \multicolumn{2}{|c|}{ Virgin Olive Oils } \\
\hline & $\begin{array}{l}\text { Sales } \\
\text { (in Thousands of Litres) }\end{array}$ & $\begin{array}{l}\text { Market Share } \\
(\%)\end{array}$ & $\begin{array}{l}\text { Sales } \\
\text { (in Thousands of Litres) }\end{array}$ & $\begin{array}{l}\text { Market Share } \\
(\%)\end{array}$ \\
\hline Distributor Brands & 144,681 & 70.06 & 40,302 & 44.40 \\
\hline $\begin{array}{c}\text { SOS Group } \\
\text { (Koipe, Carbonell, Salgado and Elosúa) }\end{array}$ & 34,204 & 16.56 & 7,813 & 8.61 \\
\hline $\begin{array}{c}\text { Ybarra-Migasa Group } \\
\text { (La Masía, Ybarra, Mueloliva, Minerva and Rafael Salgado) }\end{array}$ & 10,292 & 4.98 & 890 & 0.98 \\
\hline $\begin{array}{c}\text { Acesur Group } \\
\text { (Coosur and La Española) }\end{array}$ & 7,320 & 3.54 & 8,911 & 9.82 \\
\hline $\begin{array}{c}\text { Hojiblanca } \\
\text { Group (Hojiblanca, Cordoliva and Torcaoliva) }\end{array}$ & & & 11,898 & 13.10 \\
\hline Borges (Borges) & 2,121 & 1.04 & 1,340 & 1.47 \\
\hline El Molino De Bertín & & & 2,222 & 2.45 \\
\hline Olivar de Segura & & & 825 & 0.91 \\
\hline Oleoestepa (Oleoestepa) & & & 284 & 0.31 \\
\hline Rest & 7,874 & 3.82 & 16,289 & 17.95 \\
\hline TOTAL & 206,492 & 100.00 & 90,774 & 100.00 \\
\hline
\end{tabular}

Source: [53].

market. Thus distributor brands have a market share of $70.06 \%$ in olive oils and $44.4 \%$ in edible virgin olive oils, namely extra virgin. What is more, comparison between data in the two tables reveals a growth trend in the importance of distributor brands, both in olive oils and in virgin olive oils. This trend was affirmed by MERCASA [52], stating that sales of olive oils under a distributor brand represented $62 \%$ of total sales in the market by volume, and $53 \%$ by market value. However, the market share of distributor brands for extra virgin olive oils has witnessed a decline in recent years, dropping from $47.44 \%$ in the period July 2005 to July 2006, to the current figure of $44.4 \%$. This fall is no doubt due to the effort of producers on two fronts - achieving quality and taking it direct to the market. This is both good news and also an excellent strategy, in which the agri-district could follow the examples set by some of the cooperatives, such as the Hojiblanca Group, Olivar de Segura and Oleoestepa, in their concentration of the offer and their differentiation.

In short, olive oils are mainly obtained via self-service establishments (supermarkets, hypermarkets and discount supermarkets) belonging to the major distributors, where distributor brands occupy a prominent position in product ranges such that, in general, three or four brands of olive oils are on offer: the market leaders and the distributor brand. In the face of distributor brands, then, there is little market available for manufacturer brands and even less so for those that are little known. In light of this scenario, the agridistrict, in which the cooperative movement takes a highly visible role, is barely orientated towards the end-market, as 
evidenced by its passive commercial behaviour. Achieving a stronger presence in the bottled oils market remains an ongoing challenge, a fact which demonstrates that the strategy of multiple own-brands with low market value - too many and too small - is simply not adequate in the face of competition from bigger, more powerful distributors. As a consequence, the major distribution groups do business with suppliers that are not, in general, producers from the agridistrict grouped into cooperatives, but rather major bottling companies from the cluster. These have sufficient supply capacity, have products with differentiated brands in the market and can bottle oils under distributor brands.

\section{THE AGRI-DISTRICT'S CHALLENGES - A TERRITORIAL VISION}

The territorial perspective adopted in this article opens up possibilities for fostering the greatest number of relationships between neighbouring and peripheral sectors, public and private bodies, and centres for support and research. Such relationships can help to build a powerful network that facilitates lasting competitive advantages and contributes to diversification of the regional economy in sectors that have been shown to be competitive in the market. Approaching the agri-food industry from a territorial perspective is not only important for its capacity to sustain and grow value-added throughout the value chain. Of equal importance is its role in promoting and disseminating innovations (technological and institutional) amongst some of the less dynamic players in the territory. Over the long term this would help sustain competitiveness of the sector in international markets. Here the interest is on strengthening the use of knowledge in the agri-district and on improving constructive interaction between the different parts of the cluster, such that they might take advantage of economies that are external to companies themselves, but internal to the territory, and ultimately achieve increasing yields.

The quest for a culture of business efficiency is particularly relevant in a context such as that of the olive grove in Europe, which is set to witness an extraordinary level of change in the next few years, for instance in alterations to the protection mechanisms it enjoys today. Developing such a culture occurs more quickly where there is contact between agents from the same sector, be they producers, or created and managed by public bodies. Changes in the rural environment - short term, as a result of the new focus of the Common Agricultural Policy, and long term, because of pressure from the lesser developed countries to relax restrictions in European agricultural markets - may well suppose new challenges for the agridistrict. The evolution of local production activity should move towards greater diversification of the value chain.

In the next few years the territory is likely to have to confront a number of threats, amongst which we would highlight:

1. The trend towards greater control by the major distribution chains of the olive oils industry, which will make it more difficult to access the markets, as outlined earlier.

2. The decline in oil prices as a result of the increase in the offer, unless there is also a strategy for increasing demand. This scenario is closely related to the agri- district's behaviour (which may extend out to the rest of the olive-producing realm), namely being overly preoccupied with increasing productivity of the olive groves, and less concerned with undertaking initiatives to increase demand.

3. The proliferation in the market of substitute products to replace olive oils, of inferior quality but lower in price. This threat emerges when olive oil prices start to rise. We are already seeing mixtures made of olive oils and seed oils in the European markets.

4. Deregulation of agriculture, which will reduce aid to the sector - indeed it could make it a thing of the past. It will also bring about, through gradual elimination of border protection, an increase in competition in the home market, as a result of cheaper oils coming in from other non-Community oil-producing countries.

On the other hand, the agri-district has some major opportunities, amongst which we would highlight:

1. The upward trend in consumption of healthy, safe, quality products, as the consumer becomes increasingly conscious of the close relationship between diet and health.

2. World-wide recognition of the health and therapeutic benefits of olive oils.

3. The olive grove's position as the backbone of the territory, driving rural development and a key factor in sustaining and improving the environment.

4. The emergence of new activities such as industries based on exploiting by-products from olive groves and olive oil production, and from the use of olive oils in production by food and cosmetic industries. Therefore also key are the new prospects that are emerging as the olive grove gains in prestige for the new services it can deliver.

As regards actions to improve competitive capacity within the agri-district, these have to take into account a number of its current characteristics that may prove problematic. Thus, the small scale of olive groves could be addressed by means of cooperative activities, yet cooperation in the olive growing realm in Jaén province is practically non-existent (olive producers have joined forces to form cooperatives to turn olives into oils, but not to grow olive trees). In the same way, action needs to be taken to reduce the average age of olive grove owners and workers, and promote hand-over from one generation to the next. Restructuring of olive groves, and increasing the density of planting at least to an 'intensive' level, orographical and hydrological conditions permitting, is an appropriate strategy for ensuring that olive groves in Jaén province continue to be highly competitive in the medium and long term. Furthermore, the high percentage of olive grove owners whose main source of income is other than olive growing reduces, in our view, the scope for developing the agridistrict. This scenario distances olive farmers from the processes of commercialisation and professionalisation, while they operate not as entrepreneurs, but rather as rentiers. 
With regard to this latter, more cultural aspect, we are witnessing a process of new values being transmitted. Rural, agrarian values such as providence and good luck, rentseeking, land possession, risk aversion or commercial passivity are being replaced by values more driven by the investment efforts of public organisations and by the endogenous evolution of local and regional institutional relations. These include personal effort, business activity, acquisition of knowledge and the capacity to do business or seek out new markets [55]. The traditional cultural norms are all-too-evident, with strongly conservative behaviours visible throughout most of the agri-district. These translate into maintaining inefficient commercial structures within the operating environment of an open and competitive economy, structures that have been protected by the Common Agricultural Policy, particularly up until 1998, when the price intervention structure was abolished [6].

In either case, it is recognised at civil service level that, in addition to its economic importance, the cultivation of the olive grove and obtaining olive oils are both essential activities for the social and territorial cohesion of the regions where they are carried out. They are also of tremendous environmental value. Nowadays society demands that farming in general, and olive growing in particular, should generate public goods and services, of use not only to farmers but also for the whole of rural society and inhabitants of the urban environment. In this sense, the agridistrict of the olive grove provides public goods and healthy, high quality products, contributes to supporting the population, and fixes significant quantities of carbon dioxide which helps to mitigate climate change. It also preserves the traditional agrarian landscape and upholds biological diversity. So it is, then that the olive, as well as playing an important role in creating employment and income - it is recognised as a social crop - also contributes to shaping areas of high environmental and scenic value in Jaén province. For all these reasons, it is essential to foster competitiveness and sustainability in olive-growing territories and the olive oils sector as a whole, taking into account economic, and environmental, social and cultural aspects, as outlined in the statement of intent of the Draft Bill of the Olive Grove Law of Andalucía.

\section{CONCLUSIONS}

Throughout this article the notion of the agri-district is put forward as a unit of economic analysis in the study of olive-growing activity in Jaén province, and as an 'entity' competing in the marketplace. In light of the analysis undertaken, we draw the following conclusions.

The first is that there exists what we might term a significant 'commercialisation gap' between the activities delivered in Jaén province and the overall activity within the olive oils cluster world-wide. Therefore, one of the key strategic objectives that the agri-district should be working on in the medium term is that of developing greater efficiencies in its commercialisation efforts.

The agri-district demonstrates little market orientation, even in the bulk unbottled oils market, as its behaviour is largely shaped by the approaches enshrined within the Common Agricultural Policy. Hence a change of focus, towards becoming a more open, competitive market, is one of the challenges that the agri-district needs to tackle in the near future.

In order for this to happen, greater integration with the other components of the olive oils cluster is likely to be called-for. Improved coordination and structuring of commercialisation networks, and an appropriate level of collaboration between suppliers to pool their offers, are two of the challenges being considered by the various agents that make up the agri-district, in a bid to manage the overall product offer in a more cohesive way. This more unified approach would also help to achieve greater integration downstream in the value chain and thus obtain better discounts on intermediate inputs.

The way in which relationships are managed throughout the agri-food chain between the different components of the agri-district will largely determine, in the medium term, whether strategic decisions geared towards intensifying the commercialisation of oils in the end-markets are likely to succeed or whether the commercial focus will continue to centre on the bulk unbottled oils market. Even in the latter case, an increase in cooperation amongst local agents will still be required if price volatility is to be avoided.

The second conclusion relates to the environmental sphere. One of the most important roles played by agrarian activity (and indeed one of its greatest challenges) is to positively care for the environment. Jaén's olive growing agri-district has a dual opportunity to contribute to sustainable development. On the one hand, given the sheer volume of trees involved, it is a major $\mathrm{CO} 2$ drain and as such makes its own contribution to addressing this global concern. On the other hand, it faces the tremendous challenge of achieving greater sustainability at local process level and making improvements in efficiency and productivity, working towards a more sustainable type of agriculture.

The third conclusion is that the agri-district has the capacity to expand its range of activities, in a process of concentric diversification. The multi-functionality of the rural territory in which olive growing is undertaken is patently clear - for example in energy terms, in new research services such as the biotechnology field, in agritourism, and in ground-breaking financial or environmental services.

In order to make headway in this diversification process, greater investment in the 'intangibles' is required, namely in the development of human capital, and in research, development and innovation. In this sense, one of the greatest challenges facing the agri-district is to bring on board high quality professionals who are capable of taking forward new and emerging approaches as well as the more traditional activities.

The market continues to offer significant opportunities for developing the activity of Jaén's olive growing agridistrict, within the context of world-wide growth in demand for olive oils. Institutional changes that are taking place both at the European level and, again, world-wide, are triggering the arrival of new competitors and obliging business owners and other local players to design strategies for dealing with the new contexts that are fast approaching. As has been witnessed throughout the centuries, the agri-district has sufficient self-regulation mechanisms in order to maintain a certain level of activity. However, the ever-increasing 
challenges it faces demand that it moves up a gear in terms of the pace at which it operates - a pace that might be characterised currently as 'slow to respond'.

By way of overall conclusion, then, at operational level the actions that might be undertaken to secure the future of the agri-district are:

1. Continual improvement in food quality and safety of olive oils. To this end, policies need to be designed that foster the promotion of food quality and safety, in order to continue providing sustainable agrarian activity throughout the territory. This would be compatible with environmental objectives that seek to combat climate change, maintain biodiversity and diversity in the landscape, and achieve efficiency in water management. In this sense, while it is necessary to reduce greenhouse effect emissions, it is also important to recognise the value of olive groves' contribution as a carbon dioxide sink.

2. The development of more efficient commercialisation, both in the bulk unbottled oils market and also in the bottled oils market, based on a philosophy of market orientation. Becoming more market-orientated implies that the agri-district has to be convinced that its future, and therefore that of the territory, lies in consumers and not in 'Brussels'. Greater market orientation demands that the agridistrict begins to understand how the market operates, in order to adequately promote the positive external economies offered by cultivating olive groves, and the olive oils themselves.

3. Sound coordination between the agri-district and the cluster, based on well integrated and appropriatelysized commercialisation structures, and greater interand intra-sectorial cooperation. This would mean cooperating to create structures of greater volume that integrate commercialisation processes - either upstream (in the form of central points of sale) or downstream (central purchase and service points), or in both directions. Ultimately this is about seeking consolidation of all sectors throughout the agri-food chain.

4. Improvement of the workings of the agri-food chain and of the relationships between the various links within in. This requires sustainable relationships to be fostered, based on a shared market, greater transparency throughout the chain to promote competitiveness, and adjustment to price volatility.

5. The efficient management of production structures, and improvements to productivity, within a framework of agricultural sustainability.

6. Investment in the intangibles: Research and Development and Innovation, training, and increasing human capital. In this sense, it is advisable that political steps be taken to ensure development in research, innovation and training.

7. Increased diversification within the agri-district, in the form of new business opportunities and different activities associated with olive groves - rural tourism, to give but one example.
8. Promote internationalisation, which will improve the profile of local olive oils in international markets.

9. Push for policies that help develop demand, for which it is vital to invest in promotion.

10. Step up professionalisation within the sector, bringing in professionals to deliver the various different activities undertaken in Jaén province olive grove agri-district.

\section{REFERENCES}

[1] Porter ME. The competitive advantage of nations. New York: The Free Press 1990.

[2] Becattini G. Del "settore industriale" al "distreto industriale". Alcune considerazione sul unitá di indagine dell economia industriale. Rev Econe Polit Indust 1979; 1: 7-21.

[3] Aydalot P. Milieux Innovateurs en Europe. París: Economica 1986.

[4] Rivas M. Re-thinking mature districts and new emergent realities: cluster development in southern Spain. Policy workshop on local and regional clustering of R\&D. Helsinki 2002.

[5] Ferraro FJ, Aznar JA. El distrito agroindustrial de Almería: un caso atípico. In: Soler V, Ed. Los Distritos Industriales, Almería: Colección Mediterráneo Económico, Cajamar 2008; pp. 353-81.

[6] Rodríguez-Cohard JC. Desarrollo endógeno en la región urbana de Jaén. Jaén: Diputación Provincial de Jaén 2003.

[7] Rodríguez-Cohard JC. Identificación de los sistemas productivos locales de la provincia de Jaén. Observatorio Económico de la Provincia de Jaén 2005; 104: 117-53.

[8] Juste JJ. Desarrollo local y mercado global: los sistemas productivos locales y la industria agroalimentaria en Castilla y León. PhD Doctorate in Economics. University of Valladolid 2001.

[9] Larreina M, Aguado R. Beyond the cluster: how wine drives regional economy to success: "Oenopolis", the case of Rioja. Int J Wine Buss Res 2008; 20(2):153-70.

[10] Jacobs D. Innovación centrada en el conocimiento: posibilidades del enfoque basado en los clusters. IPTS Rep 1997; 16: 23-9.

[11] Calvet J. Les clusters vitivinicoles français a AOC. Une analyse en termes de biens clubs. Revue d’Economie Régionale et Urbaine 2005; 4: 481-506.

[12] Tavoletti E. The role of universities in supporting local agroindustry. Indust Higher Educ 2008; 22(6): 411-24.

[13] Muchnik J, Sautier D. Proposition d'action thématique programmée: systems agroalimentaries localizés et construction de territories. Montpellier: Cirad 1998.

[14] Sanz J, Macías A. Quality certification, institutions and innovation in local agro-food systems: protected designations of origin of olive oil in Spain. J Rural Stud 2005; 21: 475-86.

[15] Muchnik J, Pichot JP, Rawski C, Sanz, J, Torres G. Systèmes Agroalimentaires Localisés. Cah Agri 2008; 17(6): 505-613.

[16] Muchnik J, De Sainte C, Eds. Le temps des SYAL. Paris: Quae 2010.

[17] Sanz J. Territorial externalities in local agro-food systems of typical food products. ISDA Conference: Montpellier, June 28-30, 2010.

[18] Correa CA, Boucher F, Requier-Desjardins D. ¿Cómo "Activar" los sistemas agroalimentarios localizados en América Latina? Un análisis comparativo. Agroalimentaria 2006; 11(22): 17-27.

[19] Parrilli MD, García R. Industrial districts in Latin America: The role of local learning for endogenous development. In Becattini $\mathrm{G}$, Bellandi M, De Propis L. Eds. A Handbook of Industrial Districts, Cheltenham: Edward Elgar 2009; pp. 585-97.

[20] Pérez-Alemán P. Cluster formation, institutions and learning: the emergence of clusters and development in Chile. Indust Corporate Change 2005; 14(4): 651-77.

[21] MacLachlan I, Townshend I. Stockyard district as industrial clusters in two western Canadian cities. West Geogr 2004; 13-14: 44-68.

[22] Porter ME. Location, competition, and economic development: local clusters in a global economy. Econ Develop Quart 2000; 14(1): $15-34$

[23] Global Agroindustrial Forum. Report on Agroindustrial sectors. FAO 2009.

[24] National Statistics Institute. Official Population Figures 2009 January 1. Available from: http://www.ine.es [cited: 15 Jan 2010]. 
[25] Sánchez JD, Gallego VJ, Araque E. Agrarian policies, productive systems and new olive grove landscapes in Andalusia. In: Frutos L, Climent E, Ruiz E, Eds. New ruralities and sustainable use of territory. Zaragoza: Prensas Universitarias de Zaragoza 2009; pp. 199-223.

[26] Descloitres J. MODIS Rapid Response Team, NASA/GSFC, Google maps. 2003; Available from: http://www.mapasespana.com/Mapas_Comunidades_Autonomas_Espana.htm [cited: 15 Jan 2010].

[27] Vera M, Castillo AL. Estudio I. Introducción, Knoleum, paisajes del olivo. Jaén: Diputación Provincial de Jaén 2008.

[28] National Statistics Institute. Economically active population survey 2009 TIII term. Available from: http://www.ine.es [cited: 15 Jan 2010].

[29] National Statistics Institute. Gross domestic product 2009 TIII. Available from: http://www.ine.es [cited: 15 Jan 2010].

[30] Junta de Andalucía. Consejería de Agricultura y Pesca. El sector del aceite de oliva y de la aceituna de mesa en Andalucía. Available from: http://www.juntadeandalucia.es/agriculturaypes ca/portal/www/portal/com/bin/portal/DGAgraria/Estudios_Prospect iva/Estudios_Informes/caracterización_de_sectores_y_productos/ol ivar1/sector_aceite/sect_ac_oliva-mesa.pdf [cited: Jan 2010].

[31] Garrido L. Olivar y cultura del aceite en la historia de Jaén. Jaén: Diputación Provincial de Jaén 2005.

[32] Ramón R. La producción y el comercio de aceite de oliva en los países del mediterráneo (1850-1938): competencia y especialización. Medit Econ 2005; 7: 329-54.

[33] Parejo A, Zambrana JF. La modernización de la industria del aceite en España en los siglos XIX y XX. In: Nadal J, Catalian J, Eds. La cara oculta de la industrialización española. Madrid: Alianza 1994; pp. 13-42.

[34] Hernández S. El crecimiento económico en una región atrasada, Jaén, 1850-1930. Jaén: Diputación Provincial de Jaén 1999.

[35] Garrido L. Historia del olivar y del aceite en Andalucía. Málaga: Sarriá 2004

[36] Becattini G. Industrial Districts. A new approach to Industrial Change. Cheltenham: Edward Elgar 2004.

[37] Porter ME, Ketels C. Clusters and industrial districts: common roots, different perspectives. In: Becattini G, Bellandi M, De Propis L, Eds. A handbook of industrial districts. Cheltenham: Edward Elgar 2009; pp. 172-83.

[38] Becattini G. Vicisitudes y potencialidades de un concepto: el distrito industrial. Econ Indust 2006; 359: 21-7.

[39] Dei Ottati G. El distrito industrial y el equilibrio entre cooperación y competencia. Información Comercial Española 1996; 754: 85-95.
[40] Vázquez-Barquero A. Endogenous Development. London: Routledge 2002.

[41] Bellet M, Colletis G, Lung Y. Economie de proximities. Revue d’Economie Régionale et Urbaine 1993; 3 [special issue]: 357-64.

[42] Boschma RA. Proximity and innovation: a critical assessment. Reg Stud 2005; 39(1): 61-74.

[43] Long A, Van der Ploeg JD. Endogenous development: practices and perspectives. In: Long A, Van der Ploeg JD, Eds. Born from within. Practices and perspectives of endogenous rural development. Assen: Van Gorcum 1994.

[44] Becattini G, Omodei Zorini L. Rural identities and globalisation. In: Becattini G. Industrial Districts. A new approach to industrial change. Cheltenham: Edward Elgar 2004; pp. 162-80.

[45] Spanish Ministry of the Environment and Rural and Marine Environs. Annual Statistical Report. 2008; Available from: http://www.mapa.es/es/estadistica/pags/anuario2008. [cited: 25 Jan 2010].

[46] International Olive Council. World olive oil figures. Available from: http://www.internationaloliveoil.org [cited: 25 Jan 2010].

[47] Agency for Olive Oil. Spanish olive cultivation. 2010; Available from: http://aao.mapa.es [cited: 25 Jan 2010].

[48] Langreo A. Tendencias de futuro en la producción y la industria del aceite de oliva. Distribución y Consumo 2001; 54: 53-96.

[49] Torres FJ, Senise O, Mozas A, Parras M, Murgado EM. La comercialización de los aceites de oliva en Andalucía: la situación de las cooperativas. Málaga: Analistas Económicos de Andalucía, Unicaja 2000.

[50] Parras M. Distribución comercial de los aceites vegetales en España: oliva virgen $v s$ oliva/girasol. Distribución y Consumo 2001; 60: 51-62.

[51] Ministry of Industry, Tourism and Commerce. Government secretary of commerce. La distribución comercial en España en 2007. Boletín Económico de Información Comercial Española 2008; 2941. Available from: http://www.revistasice.com/Rev istasICE/BICE/pagUltimoNumero?numero=2941 [cited: 15 Jan 2010].

[52] MERCASA. Alimentación en España 2008. Available from: http://www.mercasa.es/ [cited: 10 Jan 2010].

[53] AC Nielsen. Mercado del aceite de oliva (trademarks sales). Oleo 2005; pp. 106.

[54] Luque A. El futuro: concentración, sostenibilidad y nuevas oportunidades. Conference on the challenge of the olive oil sector in the new European context. Baeza: Spain, July 3, 2009.

[55] Maestre J. Cambio socio-cultural y percepción socio-económica en Andalucía. Boletín Económico de Andalucía 1999; 25: 311-26.

Received: March 18, 2010

Revised: July 16, 2010

Accepted: July 26, 2010

(c) Rodríguez-Cohard and Parras; Licensee Bentham Open.

This is an open access article licensed under the terms of the Creative Commons Attribution Non-Commercial License (http://creativecommons.org/licenses/bync/3.0/) which permits unrestricted, non-commercial use, distribution and reproduction in any medium, provided the work is properly cited. 